\title{
CLIO MEDICA
}

Volume 22: Essays in the History of Therapeutics.

Edited by W.F. Bynum and V. Nutton. Amsterdam/Atlanta, GA 1991. 146 pp. ISBN: 90-5183-266-4

Hfl. $65,-/$ US- $\$ 32.50$

The history of therapeutics has been central to the medical enterprise in all times and all places. It is also, as Guenter Risse points out in his introductory essay, a subject which is all too often neglected by historians. He analyses some of the reasons for this and urges historians to take this complex and important theme more seriously. The essays which follow range in chronology from antiquity to the $1980 \mathrm{~s}$ and in geography from the Mediterranean Basin to the New World. They touch on such matters as diet and drugs, magic and surgery, orthodox and unorthodox approaches. What they share is an attempt to get beyond the easy dismissal of almost all therapeutics before the twentieth century as meaningless and harmful and to examine concrete dimensions of the therapeutic encounter in its social, professional, religious and scientific reverberations.

Contents: Guenter B. Risse: The History of Therapeutics. Vivian Nutton: From Medical Certainty to Medical Amulets: Three Aspects of Ancient Therapeutics. Luis Garcia-Ballester: Dietetic and Pharmacological Therapy: A Dilemma among Fourteenth-Century Jewish Practitioners in the Mont pellier Area. Christa Habrich: Characteristic Features of Eighteenth-Century Therapeutics in Germany. Renate Wittern: The Origins of Homoeopathy in Germany. John Harley Warner: Science, Healing and the Physician's Identity: A Problem of Professional Character in Nineteenth-Century America. Ulrich Trohler: "To Operate or not to Operate?' Scientific and Extraneous Factors in Therapeutical Controversies within the Swiss Society of Surgery 1913-1988.

USA/Canada: Editions Rodopi, 233 Peachtree Street, N.E., Suite 404, Atlanta, Ga. 30303-1504, Telephone (404) 523-1964, Call toll-free 1800-225-3998 (U.S. only), Fax (404) 522-7116

And Others: Editions Rodopi B.V., Keizersgracht 302-304, 1016 EX Amsterdam, The Netherlands. Telephone (020) 622.75.07, Fax (020) 638.09.48 


\title{
Medical Instrument Catalogues
}

\section{on microfiche}

\author{
Advisor: Drs K.S. Grooss, Museum Boerhaave, Leiden
}

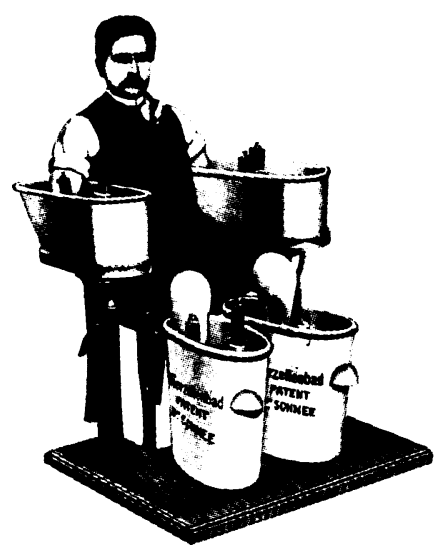

4-cell bath. Louis \&H. Locwenstein.

Elcktromedizinische Instrumente und Apparate. 1909

A microfiche collection of sales catalogues of medical instrument makers who have been advertising in printed matter since the $18^{\text {th }}$ century

This collection offers an illustrated history of medical instruments which gives a good idea of the range of instruments employed in medical procedures. An indispensable source of information for any researcher dealing with the history of medicine.

The collection contains 322 selected catalogues from the richly endowed library of Museum Boerhaave, at Leiden. The intention is to augment the microfiche collection with at least another two equivalent sets from other collections.

322 sales catalogues on 542 microfiche

Collection price: $\mathbf{5 , 4 4 5}$ guilders

\section{Brochures available free on request}

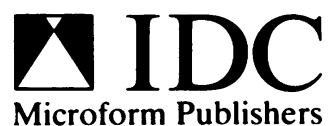

IDC bv, P.O. Box 11205, 2301 EE Leiden, The Netherlands Fax 31-71-13 1721

Dealer in the USA:

Norman Ross Publishing Inc., 330 West 58th Street, New York, N.Y. 10019 or call toll-free $800648-8850$ 


\section{Now published semiannually!}

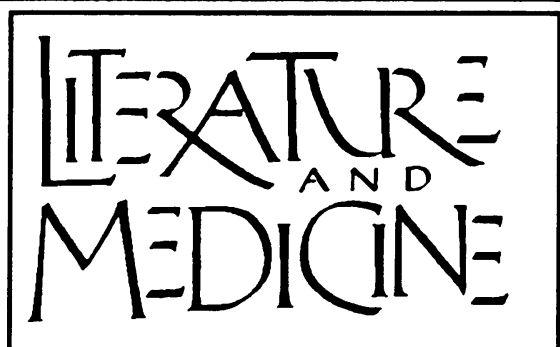

THE ART OF THE CASE HISTORY

Volume 11, Number 1, Spring 1992

Charting the Chart-An Exercise in Interpretation(s)

Suzanne Poirier et al.

Historiography, Diagnosis, and Poetics

Julia Epstein

"Is There a Person in This Case?"

William Frank Monroe et al.

Development of the Physician's Narrative Voice in the Medical Case History

David H. Flood and Rhonda L. Soricelli

Fiction and Poetry by Irena Rusenas, Cortney Davis, Jack Coulehan,

Jane Todd Cooper, and Jeanne LeVasseur

Winged Words and Chief Complaints: Medical Case Histories and the Parry-Lord Oral-Formulaic Tradition

Richard M. Ratzan

To Build a Case: Medical Histories as Traditions in Conflict Rita Charon

"A Case of Amyotrophic Lateral Sclerosis": A Reprise and a Reply David Barnard

The Politics of Narrative Form

T. Hugh Crawford

Remaking the Case

Kathryn Montgomery Hunter

$\rightarrow$ Volume 11: $\$ 18$ individuals, $\$ 32$ institutions. Foreign postage $\$ 3$, Canada and Mexico; \$5, elsewhere. Published semiannually; average length 180 pages.

$\rightarrow$ Back volumes are also available at $\$ 16.50$ each: "Toward a New Discipline" (\#1), "Images of Healers" (\#2), "The Physician as Writer" (\#3), "Psychiatry and Literature"(\#4), "Use and Abuse of Literary Concepts in Medicine"(\#5), General Issue (\#6), "Literature and Bioethics" (\#7), "The Cultures of Medicine" (\# 8); "Fictive Ills: Literary Perspectives on Wounds and Diseases" (\#9); Tenth Anniversary Retrospective (\#10).

- Send orders to: The Johns Hopkins University Press, Journals Division, 701 West 40th Street, Suite 275, Baltimore, MD 21211-2190, or call toll-free 1-800-537-JHUP for VISA and MasterCard orders.

THE JOHNS HOPKINS UNIVERSITY PRESS 


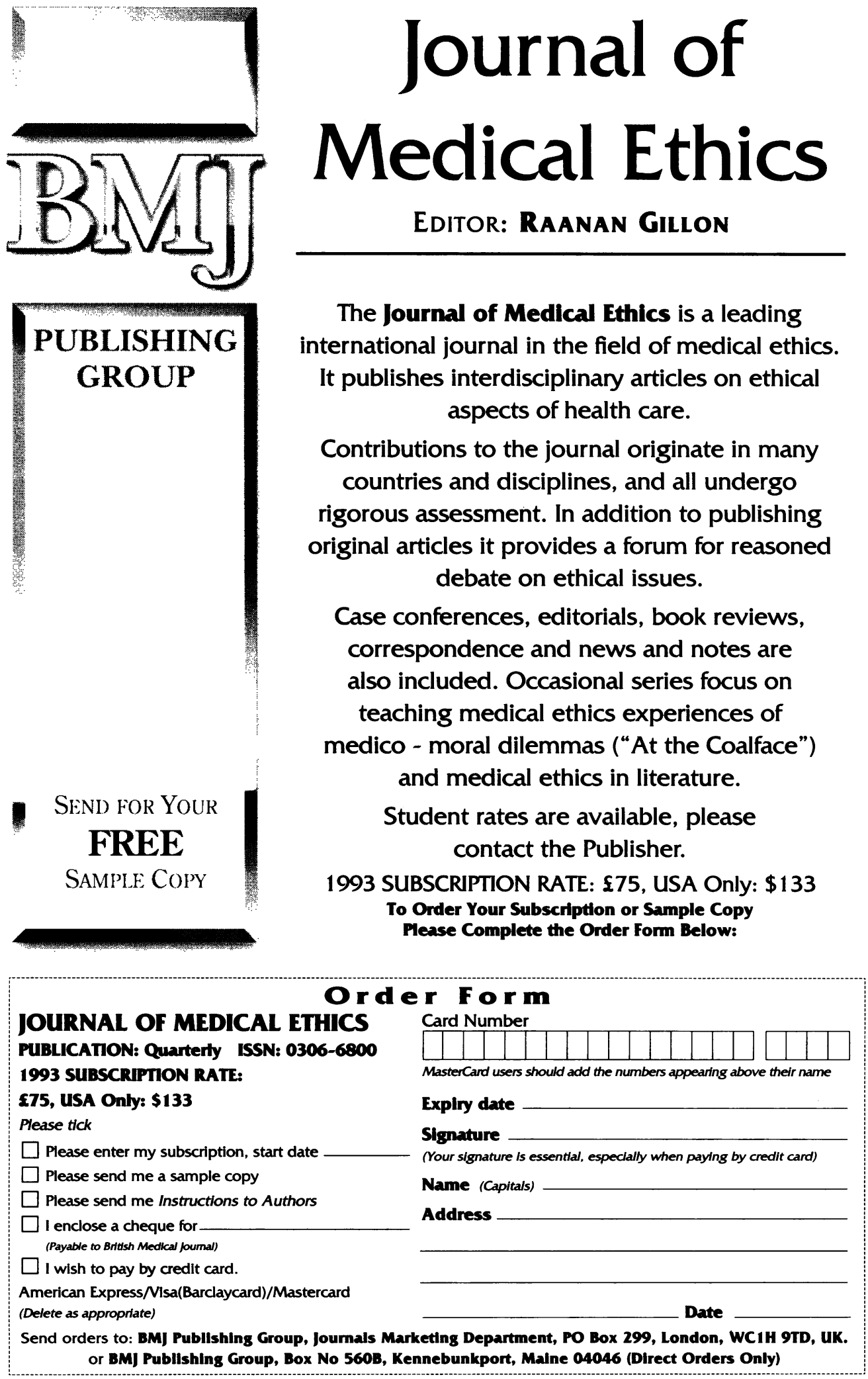


Rare Books \& Manuscripts in the history of

Medicine $\mathcal{E}$ the Sciences

Bought $\bullet$ Sold $\bullet$ Appraised

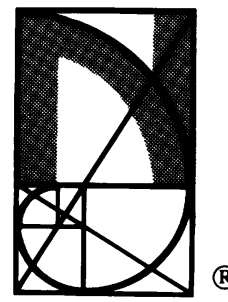

Send for our latest catalogue Jeremy Norman \& Co., Inc. 720 Market Street San Francisco, California 94102 (415) 781-6402 FAX (415) 781-5507

\section{Nigel $\underset{\text { qhillips }}{\phi}$}

Antiquarian books in the history of medicine and the health sciences.

Please send for my catalogue, or telephone for an appointment when in London.

\section{BURLEIGH PLACE PUTNEY \\ LONDON SW15 6ES \\ ENGLAND \\ Tel: 081-788 2664}

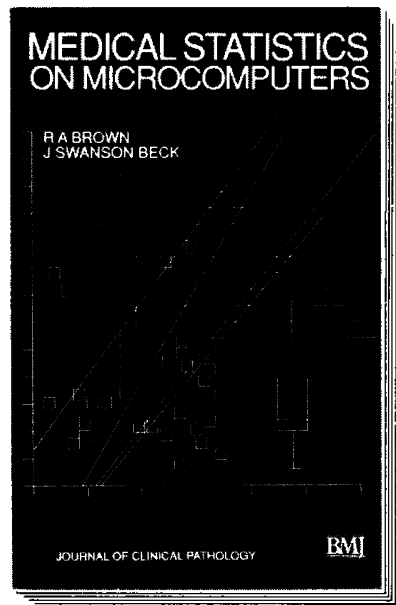

UK £8.95; Abroad $£ 10.50$

BMA members: $£ 8.45$ or $€ 10.00$ including postage by air abroad

\section{How is no longer a problem - but there's still which and why}

The microcomputer revolution has made powerful machines and highly complex programs generally available. This means that users of statistical techniques need no longer be concerned with the arithmetical and algebraic details - the software will take care of all that. What is vital, however, is to understand the ideas and the basic principles of statistical analysis. In Medical Statistics on Microcomputers R A Brown and J Swanson Beck show how to get the best use out of microcomputers when analysing data, particularly in the pathology laboratory. They explain the rational basis of various widely applicable statistical methods and also indicate their limitations so that you can make an informed choice. Chapters include:

- Data handling

- Analysis of data from one or two groups

- Comparison of several groups

- Analysis of categorical data

- Statistical methods for diagnostic tests.

Available from: BRITISH MEDICAL JOURNAL, PO BOX 295, LONDON WCIH 9TE, any leading bookseller or the $B M F / B M A$ bookshop in BMA House.

Please enclose payment with order, or send us full details of your MASTERCARD, VISA or AMERICAN EXPRESS credit card. 